\title{
THE ROLE OF JOHN THE BAPTIST LALANGUE IN THE DEVELOPMENT OF CROATIAN PUBLIC HEALTH AND MIDWIFERY IN THE CONTEXT OF IMPLEMENTATION OF THE IMPERIAL PUBLIC HEALTH LAW FROM 1770
}

\author{
Rajko Fureš ${ }^{1}$, Dubravko Habek ${ }^{2}$,Zlatko Hrgović ${ }^{3}$ and Dora Fureš ${ }^{4}$ \\ ${ }^{1}$ Department of Gynecology and Obstetrics, Zabok General Hospital and Croatian Veterans Hospital, Zabok, \\ and Faculty of Dental Medicine and Health in Osijek, Faculty of Medicine in Osijek, \\ Josip Juraj Strossmayer University of Osijek, Osijek, Croatia; \\ ${ }^{2}$ Department of Obstetrics and Gynecology, Sveti Duh University Hospital \\ and Croatian Catholic University, Zagreb, Croatia; \\ 3 Johann Wolfgang Goethe University, Frankfurt am Main, Germany; ${ }^{4}$ School of Medicine, \\ University of Split, Split, Croatia
}

\begin{abstract}
SUMMARY - To understand the development of public health in Croatia, there are newer insights into the life and work of John the Baptist Lalangue. John the Baptist Lalangue is most valued for implementation of the imperial law on public health and promotion of midwifery in Croatia during the second half of the $18^{\text {th }}$ century. Lalangue is the author of the first printed medical textbook in Croatian, published in 1776, entitled Medicina ruralis iliti Vrachtva ladanyszka, za potrebochu musev, y sziromakov Horvatczkoga orszaga y okolu nyega, blisnesseb mest, Trattnern, Varaždin. In the same period, Lalangue published the first Croatian midwifery textbook entitled Brevis institute de reobstetritia iliti kratek navuk od mestrie pupkorezne za potrebochu muskeh y sziromaskeh ladanovskaya horvatskoga orszaga y okolo nyega blisnesseh sztrankih, Trattnern, Zagreb. In 1779, Lalangue published his balneological debut in Croatian, the book Tractatus de aquis medicati Regnorum Croatiae et Slavoniae Iliti Izpiszavanye vrachtvenih vod Horvatzkoga y Slavonskoga orszaga y od nachina nye vsivati za potrebochu lyudib, Trattnern, Zagreb. Lalangue's works were used in systematic training and education of midwives and they, as well as Lalangue, have an inevitable place in the history of Croatian midwifery. During his life and work, John the Baptist Lalangue made immeasurable contribution to the development of Croatian public health.
\end{abstract}

Key words: Protestantism; Public health; Midwifery; Obstetrics; Croatia

\section{Life and Work of John the Baptist Lalangue in the Context of the Croatian Public Health and Midwifery}

John the Baptist Lalangue (Matton, Luxembourg, April 27, 1743 - Varaždin, Croatia, May 20, 1799) is

Correspondence to: Assist. Prof. Rajko Fureš, $M D, P h D$, Zabok General Hospital and Croatian Veterans Hospital, Bračak 8, HR49210 Zabok, Croatia

E-mail: rajko.fures@kr.t-com.hr

Received November 30, 2016, accepted May 30, 2018 the founder of Croatian midwifery. He is the author of the first printed books in the field of professional medical literature in Croatian, Medicina ruralis iliti vračtva ladanjska za potrebbochu musev y sziromakov horvatczkoga orszaga y okolu nyega blisnesseh meszt in 1776 and the first Croatian midwifery textbook Brevis institutio de re obstetritia iliti kratek navuk od mestrie pupkorezne za potrebochu muskeb y sziromaskeh ladanskeh sen horvatskoga orszaga y okolo nyega blisnesseh sztrankih in 1777. He is also the author of the first Croatian origi- 
nal balneological work Tractatus de aquis medicati regnorum Croatiae et Slavoniae etc. iliti izpiszavanye vrachtvenih vod Horvatzkoga y Slavonskoga orszaga y od nachina nye vsivati za potrebochu lyudib from 1778, and the economy book Nachin jabuke zemelyszke szaditi y nye haszen obernuti za volyu polyakov horvatzkoga orszaga ochituvan in 1788. Discovering that John the Baptist Lalangue is the author of the first printed book of rules of performing midwifery practice in Croatian language is extremely important for studying the history of Croatian midwifery. The book was published by dint of Nagovorni lizt, Zagreb, Trattner, in 1785. The work provides definitive proof that Lalangue is the founder of the first Croatian midwifery school in Varaždin, and exceptionally important is that it contains the first printed midwifery oath in Croatian. The mentioned facts are not known in the currently available medical literature ${ }^{1-19}$.

Lalangue came to Croatia thanks to recommendations of Gerhard van Swieten, personal physician of the Empress Maria Theresa and creator of the imperial public health law from 1770, aimed at immediate implementation. He began his tenure in Croatia as personal physician of the Croatian ban Ferenc Nadasdy, and very soon he was appointed Varaždin county physician. He was on the same duty until his death. Lalangue's true aspirations of the Enlightenment and Reformation sought improving the conditions of life of Croats, where he gave an invaluable contribution in the scientific and publishing activities, as well as in public health ${ }^{1-19}$.

\section{Impact of Physician John the Baptist Lalangue Regarding Public Health and Midwifery in Croatia}

In the context of study of the public health development and the role of the imperial public health law from 1770, Lalangue published the first Croatian midwifery regulations. The book was published in Zagreb by Trattner in 1785 . The cover tells us that John the Baptist Lalangue is a doctor, master of midwifery skills and official physician of Varaždin County. It can be seen from the headlines that the rules were official for all licensed midwives of Varaždin County. As the most important reason for publishing midwifery regulations, Lalangue highlights numerous errors during deliveries that had ended with perinatal death or caused permanent maternal or fetal damage, and tells midwives that the same mistakes can be prevented. Lalangue had already pointed to these problems in his earlier works ${ }^{1,2,5}$.

On pages 4 and 5 of midwifery regulations Lalangue says that, for these reasons, a well trained midwife and especially those who are moved by love for fellow human beings should always be called. He founded and launched Midwifery School in Varaždin, where many midwives from all parts of the Varaždin County received education at public expense. In order not to forget the knowledge and rules acquired by education, midwives had Lalangue's Midwifery Textbook as a reliable guide in performing midwifery services. As he wrote and highlighted in his earlier books, midwives are always in front of public eyes, so they should be able to keep the quality and honest model of midwifery, which they could best learn from the preface of his Midwifery Textbook. Lalangue stated that it was better for further education of midwives to prepare ten rules which they are required to comply with (pages 5-10 in the original text). The first rule Lalangue brings on page 5 , stating that midwives have to strictly adhere to the oath of midwifery. The second rule (page 6) says that midwives should receive compensation for their service, as it is a custom in the countryside. He also speaks in their favor in the third rule, stating that midwives of honest service should be fairly paid. The fourth rule (pages 6 and 7) prohibits midwives to drink (drinking was a major issue at the time). Lalangue says that the good posture must give a good example, and drunkenness stands out as a very bad habit that leads to numerous mistakes during childbirth and to unintended consequences for mothers and children. In case of violation of the rule, Lalangue warns that midwives will bear full responsibility "before God and people". The fifth rule says that midwives should comply with the rules with dignity of performing midwifery professionally, in order to ensure protection of the county official. The sixth rule (page 7 in the original text) is added in the same paragraph, stating that midwives are free to achieve their rights if someone threatens them or does not want to give them the required award after the delivery. They can report these cases to the county surgeons, to him personally, to the feudalist (it was the time of feudal order) or to cantonal judge. According to the seventh rule (pages 7 and 8), midwives are required not to abuse their duty and authority, but to 
keep improving the reputation of their midwifery profession. Lalangue further orders full compliance with what they have learned during their studies because the errors that could occur due to their different treatment can be extremely adverse. In order to prevent practices of midwifery services different from that taught in midwifery school and recommended by his Midwifery Textbook, the eighth rule (pages 8 and 9 in the original text) describes the obligation for midwives to undergo yearly crosscheck of their knowledge and skills in front of him as an official county physician or in front of surgeons. These rules are written for the midwives' own good and to eliminate as many errors as possible. At the same time, these rules warn of the penalties for noncompliance. The ninth rule (pages 9 and 10) says that the midwives are required to visit prayers and to do the tutorial with midwifery manual, which they received from him at the end of training in Varaždin. In addition, the box with recommended midwifery instruments assigned by the famous county official should be checked. Bringing a variety of herbs that will be commended especially in front of the county government is also required, and those that are new and worthy would be added in their collection. The last (tenth) rule for midwives (page 10) states that in case of need, they can contact him or official Varaždin county midwife (Elizabeth Gärtin), who is grateful to him for the quality of education and receiving midwifery honors. The first book of Croatian midwifery regulations Lalangue ends by saying that midwives should from their hearts want to keep, defend and lead themselves through good and omnipotent God, which helps their service and life, in order to live healthy and happy for the benefit of their fellows (pages 10 and 11 of the original text). Lalangue's work is ended with the date July 5, 1785, and his signature, Ivan Lalangue, Physician of the Varaždin County ${ }^{5}$.

\section{The Atmosphere of the Enlightenment, the Historical Context and Advances in Public Health and Midwifery at the Time of the Life and Work of John the Baptist Lalangue}

For the above-mentioned Midwifery Textbook and Regulations, the proof can be found in the letter Lalangue addressed to Varaždin County on December 10, 1785. The letter is a valuable contribution to the study of midwifery and public health at the end of the $18^{\text {th }}$ century ${ }^{2,5,20-27}$. This fact confirms that Lalangue is the true founder of the Croatian midwifery and founder of the first Midwifery School in Varaždin. Concerning his great knowledge, Lalangue belongs to the Croatian greats not only in the field of medical science. Thanks to him, Croatian midwives had the first printed textbook and the first printed rules for conducting midwifery practice in Croatian language. This is the first tutorial and regulation textbook of midwifery in southeastern Europe. Lalangue's legacy and immeasurable merit prompted the development of midwifery and publishing in the Croatian public health and medicine in general. Today, we can be proud remembering his great and exceptional merit, and we can be inspired by his life and grandiose works and works in publishing area ${ }^{5-10,14,15,22,24,27-30}$.

The Midwifery Ordinance by John the Baptist Lalangue is his fourth preserved medical professional work in Croatian and his second professional medical work printed in Croatian in the field of midwifery (the first was his Midwifery Textbook). Special value, which is linked to the mentioned midwifery regulations, gives us definitive confirmation of the scientific knowledge that Lalangue founded the first Croatian Midwifery School in Varaždin, which operated during his lifetime under his leadership and with great support by Elizabeth Gärtin, the Varaždin County midwife.

Of particular importance are findings obtained by analysis of the letter that Lalangue wrote to Varaždin County on December 10,1785. There we find that former midwives were required to undergo annual testing of the required knowledge, skills and conditions, also recommending midwifery supplies, books and rule. The mentioned test was a prerequisite for further official county approval for further free and official performing midwifery practice, and the point is the first official example of relicensing for the area of Croatia. Midwifery Ordinance also includes the first printed midwifery oath in Croatian, based on the Normativum sanitatis (imperial law on public health from 1770). Until these days, the midwife ordinance was further processed in medical and scientific literature, where it was evaluated as significant, confirming that Lalangue is indeed founder of midwifery education in Croatia. Midwives had mandatory midwifery license, but they had an obligation of annual relicensing. Thanks to this analysis, we came to the important insights into the conditions in the Croatian public health and midwife- 
ry at the end of the $18^{\text {th }}$ century. Based on previous findings, available documents, as well as under these midwifery regulations, Lalangue is rightfully called founder of the Croatian midwifery. Confirmation of these facts already exists in the preface to his Midwifery Textbook, as well as in the aforementioned documents. The role of John the Baptist Lalangue in the development of Croatian midwifery, public health and medicine is certainly invaluable, and for all of us an example of how to love our own country, and that all the love and knowledge should be invested in its prosperity 2,5,9,10,19,20.

\section{Lalangue's Magnificent Legacy to the Croatian Public Health and Midwifery}

The first Croatian Midwifery Textbook and Regulations, written by John the Baptist Lalangue, indeed represent an exceptional contribution to the development of the Croatian public health and Croatian midwifery in particular. It is certain that without these magnificent works, there would be no Croatian midwifery as we know it today. Lalangue is also the author of the first printed midwifery oath in Croatian, which is contained in the Midwifery Regulations.

Lalangue is the real founder of midwifery education in Croatia. Upon completion of the first Croatian Midwifery School in Varaždin, midwives passed the recommended examination and received license for midwifery work. Older midwives had to do annual relicensing. It is the basis on which the education of Croatian midwives has relied down to the present. It is in accordance with the foundations of modern midwifery. Based on these findings, Lalangue's role in the development and history of Croatian midwifery becomes even more important, and we can reasonably say, magnificent. Everything we have mentioned is extremely important in the context of studying the history of the Croatian public health and midwifery, and the first midwifery regulations and tutorials are extremely worthy works. The mentioned works give us the basis for further study of the roots of the Croatian public health and midwifery. These scientific findings only confirm the greatness of John the Baptist Lalangue in the history of Croatian medical professional printed literature, in the history of Croatian midwifery training and in the history of Croatian midwifery, and presents an incentive for further research of Lalangue's role in the history of Croatian medicine. Especially the history of Croatian midwifery is worth to be evaluated as he deserves. What is also particularly important to know is that the analysis of John the Baptist Lalangue's works tells us the exact situation in the Croatian health system, which is, despite the feudal order, part of the modern world. Under the auspices of the former Austro-Hungarian Empire, Croatia was able to experience all benefits of the Enlightenment that were possible. From a very well regulated state, in the time to come Croatia turned to stagnancy due to some other forms of integration, which not only blocked historical development of the Croatian society, science and medicine, including midwifery, but also all aspects of the society. Today, when Croatia is full EU member, we remember with pride John the Baptist Lalangue and his work. It is the best example of pride and belonging to the modern world and civilization for many centuries, as well as today. Croats should always be proud with the contribution they have always offered to $\mathrm{Eu}-$ rope. The contribution was and is truly worth, full of respect and pride pr,5,30. $^{2}$.

\section{References}

1. Lalangue JB. Medicina ruralis iliti vračtva ladanjska za potrebbochu musev y sziromakov horvatczkoga orszaga y okolu nyega blisnesseh meszt. Varaždin: IT Trattner, 1776. (in early Croatian 639-3 KJV)

2. Lalangue JB. Brevis institutio de re obstetritia iliti kratek navuk od mestrie pupkorezne za potrebochu muskeh y sziromaskeh ladanskeh sen horvatskoga orszaga y okolo nyega blisnesseh sztrankih. Zagreb: IT Trattner, 1777. (in early Croatian 639-3 KJV)

3. Lalangue JB. Tractatus de aquis medicati regnorum Croatiae et Slavoniae etc. iliti izpiszavanye vrachtvenih vod Horvatzkoga y Slavonskoga orszaga y od nachina nye vsivati za potrebochu lyudih. Zagreb: IT Trattner, 1778. (in early Croatian 639-3 KJV)

4. Lalangue JB. Nachin jabuke zemelyszke szaditi y nye haszen obernuti za volyu polyakov horvatzkoga orszaga ochituvan. $\mathrm{Za}-$ greb: Kotsche, 1788. (in early Croatian 639-3 KJV)

5. Lalangue JB. Nagovorni lizt. Zagreb: IT Trattner, 1785. Hrvatski državni arhiv, Zagreb, Kut. 62. (in early Croatian 639-3 KJV)

6. Grmek MD. O meštriji pupkoreznoj. Zagreb: Biblioteka Kulturno-prosvjetnog društva Hrvatskih Zagoraca "Matija Gubec", 1958; Vol. 5. (in Croatian)

7. Thaller L. Povijest medicine u Hrvatskoj i Slavoniji od godine 1770. do godine 1850. Lijec Vjesn. 1926;81:531-4. (in Croatian) 
8. Belicza B. Mjesto i uloga J. B. Lalanguea u razvoju zdravstvenog prosvjećivanja i hrvatske medicinske terminologije na području sjeverne Hrvatske u 18. stoljeću. Lijec Vjesn. 1976; 98:211-5. (in Croatian)

9. Fureš R, Dražančić A, Blažeka Đ, Cesarec I, Kopjar M, Šanjug J, Zadro M, Krajcar M. Ivan Krstitelj Lalangue i njegova prva medicinska stručna knjiga iz područja primaljstva na hrvatskome jeziku. Gynaecol Perinatol. 2010;19(1):44-54. (in Croatian)

10. Fureš R. Začetnik suvremenog hrvatskog porodništva i primaljstva Joannis Baptiste Lalangue (Ivan Krstitelj Lalangue) i njegov prvijenac stručne medicinske književnosti s područja primaljstva na hrvatskome jeziku - knjiga Brevis institutio de re obstetricia iliti kratek navuk od mestrie pupkorezne za potrebochu muskeh y sziromaskeh ladansleh sen horvatskoga orszaga y okolo nyega blisnesseh sztrankih (Zagreb, 1777), u kontekstu razvoja hrvatskoga primaljstva i porodničke struke. Nova bolnica. 2009;25(7):41-6. (in Croatian)

11. Fureš R. Prva tiskana medicinska stručna knjiga iz područja primaljstva na hrvatskokajkavskome jeziku Ivana Krstitelja Lalanguea. Hrvatsko zagorje. 2009;3-4:174-94. (in Croatian)

12. Fureš R, Šanjug J. Ivan Krstitelj Lalangue - začetnik sustavne izobrazbe hrvatskih primalja. Gynaecol Perinatol. 2010;19 (Suppl 1):150. (in Croatian)

13. Dražančić A. Povijest ginekologije i perinatologije u Hrvatskoj. Lijec Vjesn. 1999;121:100-8. (in Croatian)

14. Dražančić A, Kurjak A. Hrvatska perinatologija. Prošlost, sadašnjost i budućnost. Gynaecol Perinatol. 2002;11(2):53-68. (in Croatian)

15. Glesinger L. Medicina u svijetu i u nas prije 100 godina. LijecVjesn. 1977;99:58-61. (in Croatian)

16. Pintar I. Porodništvo. Medicinska enciklopedija. Zagreb: Jugoslavenski leksikografski zavod, 1970;326-30. (in Croatian)

17. Jembrih A. Ivan Krstitelj Lalangue i njegovo djelo. Krapina: Hrvatsko zagorje. 2000;6(2). (in Croatian)

18. Puškadija Ribkin T. Neke nepoznato-poznate starokajkavske knjižice. Kaj. 1998;31:27-35. (in Croatian)
19. Jembrih A. Ivan Krstitelj Lalangue (1743.-1799.) u službi zdravstva horvatskoga orsaga u 18. stoljeću. Gazophylacium. 1999;4(1-2):74-85. (in Croatian)

20. Forenbacher G. Povijest Zbora liječnika. In: Grmek MD, Dujmušić $\mathrm{S}$, editors. Iz hrvatske medicinske prošlosti. Zagreb: Croatian Medical Association, 1954. (in Croatian)

21. Jamnicki-Dojmi M. Primaljska škola u Zadru od utemeljenja 1820. do Rapallskog ugovora 1920. In: Jamnicki Dojmi M, editor. 175 godina od početka rada Primaljske škole. Zadar, 1996. (in Croatian)

22. Kuzmanić A. Šezdeset učenjah iz primaljstva za primalje. Zadar: Škola za primalje, 1885. (in Croatian)

23. Lallich N. Knjiga za primalje. Zadar: Škola za primalje, 1908. (in Croatian)

24. Piskaček I. Udžbenik za učenice primaljskog tečaja i priručna knjiga za primalje. Prijevod IV. njemačkog izdanja (A. Strmich). Zadar, 1911. (in Croatian)

25. Bunjevac H, Dugački V, Fatović-Ferenčić S. Sto dvadeset godina Škole za primalje u Zagrebu. Zagreb: Gandolf, 1997. (in Croatian)

26. Habek D. Kraljevsko zemaljsko primaljsko učilište i zemaljsko rodilište u Zagrebu 1894.-1895. godine. Gynaecol Perinatol. 2009;18(2):87-9. (in Croatian)

27. Lobmayer A. Primaljstvo. Učevna knjiga za primalje. 2.izdanje. Zagreb: Hrvatsko-slavonsko-dalmatinska vlada, 1889. (in Croatian)

28. Piasek G. Zdravstvo Varaždina do konca 19. stoljeća. Radovi Zavoda za znanstveni rad HAZU Varaždin, 1994;6-7:213-72. (in Croatian)

29. Stipešević Rakamarić I. Short notes from history of health care in Varaždin County. Crtice iz povijesti varaždinske županije. Pripremila Irena Stipišević Rakamarić iz radova prim.dr. Gustava Piaseka. HČZJZ. 2007;3:11.

30. Kusić Z, Fatović-Ferenčić S. Od kupališnog liječnika do bolnice. 800 godina slobodnog kraljevskog grada Varaždina 1209.2009. Zbornik radova s međunarodnog znanstvenog skupa održanog 3. i 4. prosinca 2009. Godine, Varaždin, 2009; p. 8639. (in Croatian) 
Sažetak

\title{
ULOGA IVANA KRSTITELJA LALANGUEA U RAZVOJU HRVATSKOGA JAVNOG ZDRAVLJA I PRIMALJSTVA U KONTEKSTU PROVEDBE CARSKOG ZAKONA O JAVNOM ZDRAVSTVU IZ 1770. GODINE
}

\author{
R. Fureš, D. Habek, Z. Hrgović i D. Fureš
}

Za razumijevanje razvoja javnoga zdravstva u Hrvatskoj bitne su novije spoznaje o životu i radu Ivana Krstitelja Lalanguea. Ivan Krstitelj Lalangue je najzaslužniji za provođenje carskoga zakona o javnom zdravstvu iz 1770. godine i promicanja primaljstva u Hrvatskoj tijekom druge polovice 18. stoljeća. Lalangue je autor prvog tiskanog originalnog medicinskog udžbenika na hrvatskom jeziku ("Medicina ruralis iliti Vracbtva ladanyszka, za potrebochu musev, y sziromakov Horvatczkoga orszaga i okolu nyega, blisnesseh meszt", Trattnern, Varaždin, 1776.). Lalangue je autor i prvog hrvatskog primaljskog udžbeni$\mathrm{ka}$ ("Brevis institutio de reobstetritia iliti kratek navuk od mestrie pupkorezne za potrebochu muskeh y sziromaskeh ladanskeh sen horvatskoga orszaga y okolo nyega blisnesseh sztrankib", Trattnern, Zagreb, 1777.). Isto tako, Lalangue je autor i hrvatskog balneološkog prvijenca ("Tractatus de aquis medicati regnumum Croatiae et Slavoniae, iliti Izpiszavanye vrachtvenih vod Horvatzkoga i Slavonskoga orszaga i od nachina na sveznati za potrebbochu lyudib", Trattnern, Zagreb, 1779.). Lalangueovi su radovi korišteni u sustavnom obrazovanju hrvatskih primalja te su imali nezaobilazno mjesto u povijesti hrvatskoga primaljstva. Njegova su djela i cjelokupni život unaprijedili javnozdravstvene uvjete na područje Hrvatske pa isti temeljem novijih spoznaja dobiva sve veće značenje.

Ključne riječi: Protestantizam;Javno zdravstvo; Primaljstvo; Porodništvo; Hrvatska 